\title{
China, Great Power Responsibility and Arctic Security
}

Kopra, Sanna

Palgrave Pivot

2019-08

Kopra , S 2019 , China, Great Power Responsibility and Arctic Security . in L Heininen \& H Exner-Pirot (eds), Climate Change and Arctic Security : Searching for a Paradigm Shift .

Palgrave Pivot , pp. 33-52 . https://doi.org/10.1007/978-3-030-20230-9_3

http://hdl.handle.net/10138/332711

https://doi.org/10.1007/978-3-030-20230-9_3

acceptedVersion

Downloaded from Helda, University of Helsinki institutional repository.

This is an electronic reprint of the original article.

This reprint may differ from the original in pagination and typographic detail.

Please cite the original version. 


\title{
China, great power responsibility and Arctic security
}

\author{
Sanna Kopra \\ In: Lassi Heininen \& Heather Exner-Pirot (eds.) (2020), Climate Change and Arctic Security. Searching for a \\ Paradigm Shift. Cham: Palgrave MacMillan, pp. 33-52.
}

\begin{abstract}
Based on the basic premise of the English School theory of International Relations that great powers have a unique responsibility to uphold international peace and security, this chapter examines the ways in which China's notions of great power responsibility guide its policies in the Arctic. Thereby the chapter seeks to increase our understanding of what kind of a great power China will be and how its rise may shape the discourses, premises and paradigms of international security in the future. Since there seems to be no real risk of a military conflict in the Arctic, and since China's growing engagement is unlikely to induce such a risk, the chapter will focus on China's contribution to the most imminent security risk in the region: climate change. The chapter demonstrates that although the Chinese government has started to define climate responsibility as an important attribute of great power responsibility at a global level, China's Arctic policy does not make reference to this special responsibility even though climate change generally seems to be one of the key drivers of China's Arctic engagement. Finally, the chapter concludes that because notions of great power responsibility derive from the practices of security politics, it is not very likely that China - or the United States - will assume a strong climate leadership role without a profound normative transformation in the discourses and premises of international security.
\end{abstract}

\section{Introduction}

Over the last thirty years, international society has been shaped by two significant changes that are likely fuel a paradigm shift in international security. In particular, climate change has emerged as a key threat of our times. It inevitably poses serious concerns over human security around the world, as it affects the lives of all the people on the planet by increasing the frequency and intensity of extreme weather events, rising sea levels and changing precipitation patterns, for instance. Developing countries - especially the poorest people living in those countries - and small island states in the Pacific and Indian Oceans are most likely to be harmed by the adverse effects of climate change and they do not often have enough resources to adapt to it. In addition, the polar regions are very vulnerable to climate change. In the Arctic, temperatures have risen more rapidly than in any other region on Earth during the last 30 years. As a result, sea ice, permafrost and the snow cover have decreased dramatically, hampering the livelihoods of local people and threatening the survival of many Arctic species such as polar bears, walrus and seals (see, for example, Serreze, 2018). Moreover, the melting of ice and permafrost in the High North accelerates climate change and alters ecosystems globally (ACIA, 2004; AMAP, 2017). The People's Republic of China (hereafter China or PRC) has undergone a dramatic identity change from an isolated communist state to an (emerging) great power that cannot be ignored in any sector of politics or economic life, including regional affairs in the Arctic. This identity transformation has significantly transformed its sphere of interests and raised global concern about it being a revisionist power seeking to challenge the status quo. Owing to China's growing interest in the Arctic, many regional actors fear that China will challenge the rights and interests of the Arctic states and raise the risk of a military conflict in the region (see, for example, Cassotta et al., 2015; Rainwater, 2013; Wright, 2011). Instead of directly engaging in this debate, I study the practices of international security from another angle by investigating the ways in which China's notions of great power responsibility guide its policies in the Arctic. In this way, I seek to increase our understanding of what kind of a great power China will be and how its rise may shape the discourses, premises and paradigms of international security in the future. 
Consequently, my chapter departs from the work of classic realists, who believe that international relations are 'condemned to perpetual great-power competition' (Mearsheimer, 2001, p. 2) and hence the rise of a new great power, China, unavoidably causes a hegemonic war. Conversely, I underscore the fact that there is no natural law determining the behaviour of rising powers and that their conduct is influenced by circumstances and ideas instead. In comparison to previous rising powers, China's rise takes place in a very different international architecture that has brought about new global concerns. On the other hand, China's cultural-historic background, ideologies and values influence its priorities in international relations and its behaviour in different situations. I build here on the English School theory of International Relations and start from the fact that a central element of being a great power is to have 'fundamental global capabilities and responsibilities that minor or medium powers do not' (Jackson, 2000, p. 21). According to Shambaugh (2013), whether or not China possesses such capabilities and responsibilities at the global level remains to be debated. I argue that we must study how China's rise will change the discourses, premises and paradigms of international security, and why. Hence, it is no longer meaningful to discuss whether or not China's rise to a great power will change the practices of international society. In this chapter, I engage in this debate by elaborating China's policies in the Arctic. Since there seems to be no real risk of a military conflict in the Arctic, and since China's growing engagement is unlikely to induce such a risk, I will focus on China's contribution to the most imminent security risk in the region: climate change.

The basic tenet of English School theory is that states form an international society that exists 'when a group of states, conscious of certain common interests and common values, form a society in the sense that they conceive themselves to be bound by a common set of rules in their relations with one another, and share in the working of common institutions' (Bull, 2002 [1977], p. 13). In that society, great powers have a special responsibility to ensure its workings and to maintain international peace and security. Yet, the classic English School's focus on the security of states is somewhat outdated, as climate change will shape the ways in which security is being conceptualised and assessed in the future. In particular, human security, which stresses the protection of human beings from both traditional (i.e. military) and non-traditional security threats (such as poverty, pandemic diseases and climate change), is likely to become a more important approach to security than ever before. In this chapter, therefore, I argue that climate change is a severe security threat that cannot be fully addressed without having a paradigm shift in the future international security discourse. In particular, that shift would yield a profound normative change in international society: while great powers are generally agreed to have a unique responsibility to uphold international peace and security, they would be expected to shoulder the greatest responsibility for climate change mitigation and adaptation to it. For China, this responsibility seems to be an important justification to engage in Arctic affairs and to strive for a more influential role in the regional governance. Therefore, China's Arctic engagement provides a fruitful case to examine its practices of great power responsibility and to analyse their implications for discourses on international security.

\section{Rise of China and great power responsibility}

English School theory maintains that power and responsibility go hand in hand: the greater the power of a state is, the greater the international effect of its domestic and foreign policies will be on the workings of international society and the greater its responsibility will be for the collective well-being of the members of that society. As Watson (1982, p. 201) puts it, 'states with enough power to do serious damage to the functioning of international society should accept the responsibility not to cause such damage, but to pursue their interests with prudence and restraint'. In 1945, the United Nations (UN) Charter formally appointed great powers to have special responsibilities in international society: the permanent members of the UN Security Council (China, France, Russia, the United Kingdom, and the United States) have the 'primary responsibility for the maintenance of international peace and security' (Chapter 5, Article 24). This responsibility was largely based on great powers' material capabilities, because, according to then British Foreign Secretary Anthony Eden, 'the more power and responsibility can be made to correspond, the more likely it is that the machinery will be able to fulfil its functions' (quoted in Bukovansky et al. 2012, p. 31). In practice, great powers must modify their 'policies in the light of the managerial responsibilities they bear' in international society (Bull, 2002 [1977], p. 196). As for 
China's Arctic engagement, this means that China should be cautious not to harm the sovereign rights of Arctic states or otherwise undermine the stability in the region, as such action would be inconsistent with its great managerial power responsibility.

For Watson as well as for most of the other classic English School theorists, great power responsibility means that in a suddenly sharpened conflict, the main responsibility for peace negotiations falls on great powers. In cases of unavoidable confrontation between great powers on opposing sides, the responsibility to avoid an unnecessary resorting to force belongs to them, rather than the 'smaller and more immediate protagonists' (Watson, 1982, p. 201). In the post-World War II era, the United States (U.S.) has emphasised human rights and humanitarian intervention as key aspects of great power responsibility, since it views liberal norms as an important means to sustain the workings of international society (Kopra, 2019a, 2019b). As China is a signatory to the international human rights treaties and other key international legal frameworks, it respects liberal norms at least in principle without seeking to challenge them. In moral terms, however, China does not accept them as guiding principles of international society and instead seems to seek to transform the ways in which great power responsibility is conceptualised in the future. In these efforts, the international norms of climate responsibility play an important role, as climate change is a truly global phenomenon - not a social construction based on the cultural and philosophical traditions of the West (ibid.).

Within the English School, scholars debate on the justifications and scope of great power responsibility: pluralists stress the importance of great powers' role in fostering international order and the security of states, whereas solidarists emphasise international justice, human security and the well-being of individuals. Recent contributions to English School theory have also paid attention to the environmental responsibilities of states in general (Jackson, 2000; Falkner, 2012; Falkner \& Buzan, 2018), and those of great powers in particular (Kopra, 2019a, 2019b). Furthermore, I have argued that climate responsibility is an established international norm, and both pluralist and solidarist argumentation can be used to justify great powers' special responsibility for climate change in two respects. First, climate change is a source of potential international conflict, and great powers bear the main responsibility for the resolution of the problem owing to their functional great power responsibility to maintain international peace and security. Second, climate change causes severe harm to the well-being of individual human beings around the world, and great powers should lead global endeavours to solve it because of their diplomatic great power responsibility to promote international justice and well-being (Kopra, 2019a, p. 74).

From the English School standpoint, thus, China's rise to the status of a great power indicates that we can expect it to shoulder more responsibility in international (climate) politics in the future. At the same time, we should notice that China might not be willing to carry out such responsibilities if they do not bring along special rights in international society as well. In contrast to other states, great powers enjoy privileges in international society: they have the capability and legal authority to 'play a part in determining issues that affect the peace and security' of international society (Bull, 2002 [1977], p.196). This right is written in the UN Charter: permanent members of the UN Security Council have a right to decide on the necessary means to maintain international peace and security, including the use of military force. Their power of veto in international decision-making gives them a hegemonic position in international society and thus grants them a privilege to defend their interests or to promote particular issues and ideas in that society, for instance. This privilege makes great powers special and establishes an important source of their responsibility in international society (cf. Bukovansky et al. 2012, p. 31-32). As a permanent member of the UN Security Council and as a rising great power, China should have access to each and every international forum where decisions regarding international peace and security are made - otherwise it would be difficult for it to shoulder great power responsibility in practice. In principle, the Arctic Council is not such a forum, since issues of international security are not on its agenda. However, the situation may change if climate change will be regarded as an international security risk and an important attribute of great power responsibility. At present, great powers do not enjoy any privileges in international climate politics, because they do not carry special responsibilities, either. 
That said, there are indeed signs that climate responsibility is becoming an attribute of great power responsibility (Kopra, 2019a, 2019b). After the Cold War, people started to scrutinize the environment and many studies on environmentally induced conflicts were conducted (for a detailed overview of these developments, see e.g. Trombetta, 2008). In 1992, the UN Security Council acknowledged that the 'non-military sources of instability in the economic, social, humanitarian and ecological fields have become threats to peace and security' (UN Security Council, 1992). In the mid-2000s, climate change mitigation was also discussed in the context of security politics (Trombetta, 2008, p. 594-595). Since then, the relationship between climate change and violent conflicts has been extensively investigated (i.e Lee, 2009; Mazo, 2010; Welzer, 2012). These developments induced a debate on the role of the UN Security Council in climate change mitigation: if seen as a risk to international peace and security, climate change can and should be added to its agenda (see also Kalliojärvi's chapter in this volume). In 2007, the UN Security Council indeed organised its first discussion on the nexus between climate change, energy and international security, although China and some other states insisted that the Council was not a proper venue for such debate (United Nations, 2007). Conversely, Margaret Beckett, the British Foreign Secretary and President of the Council, argued that the UN Security Council should discuss the security impacts of climate change because the 'Council's responsibility was [is] the maintenance of international peace and security, and climate change exacerbated many threats, including conflict and access to energy and food' (Ibid.). In 2009, the UN General Assembly called upon relevant UN organizations to tighten up their climate change mitigation efforts and asked the UN Secretary-General to prepare a comprehensive report on the potential security impacts of climate change (UN General Assembly, 2009a). The Secretary-General responded by addressing five topics through which climate change could affect international security: vulnerability, development, coping and security, statelessness, and international conflict (UN General Assembly, 2009b). In 2011, the UN Security Council again discussed climate security under the German presidency. While the Council failed to issue a formal resolution on climate change or give specific recommendations on how to improve climate security, it issued the first-ever statement on the matter, expressing "its concern that possible adverse effects of climate change may, in the long run, aggravate certain existing threats to international peace and security" (UN Security Council, 2011). Two years later, informal talks were held on the topic, but because of the opposition of China and Russia, climate change was not officially defined as an international security risk (Krause-Jackson, 2013). In 2018 and 2019, the Security Council debated the nexus between climate change and conflicts again, and the debate is likely to continue in the coming years. Although the UN Security Council has not made a formal resolution on climate change, the fact that it has held several talks on the issue indicates that it has started to be regarded as a security risk, and hence great powers should bear the special responsibility to respond to it (Kopra, 2019b, p. 156).

In rhetoric terms, the United States - at least before the term of Donald J. Trump - and China have acknowledged their great power responsibility for climate change. They have stated that their climate cooperation establishes a 'powerful example that can inspire the world' (White House, 2013). In particular, President Barack Obama made an explicit link between climate change and great power status in September 2014 by announcing that the U.S. and China 'have a special responsibility to lead' the global efforts to tackle climate change because that is 'what big nations have to do' (Obama, 2014). Despite its opposition to hold a formal discussion on climate change at the UN Security Council, China seems to have started to accept the idea that great powers should lead climate change mitigation and adaptation to the problem at the global level. In September 2014, Special Envoy Zhang Gaoli (2014) announced at the UN Climate Summit that 'responding to climate change is what China needs to do to achieve sustainable development at home as well as to fulfil its due international obligation as a responsible major country'. After that, China has made all its key climate commitments public through joint statements with the United States - a choice which indicates that it has made them in reference to its great power status (cf. White House, 2014, 2015, 2016a, 2016b). In November 2016, however, the climate change sceptic Donald Trump was elected president, which ended the Sino-American leadership in international climate politics. In June 2017, the United States decided to withdrew from the Paris Climate Agreement established within the United Nations Framework Convention on Climate Change (UNFCCC) in 2015 (White House, 2017). Consequently, international society began to expect China, together with the European Union, to step into the shoes of a global climate leader. Chinese President Xi Jinping indeed 
responded to these expectations in October 2017 by announcing that China will take a 'driving seat' in international climate negotiations (Xi, 2017, p. 4).

At present, however, it remains unclear what kind of a climate leader China will be. It continues to stress the historic responsibilities of developed countries and has not indicated a willingness to substantially enhance its own, very moderate climate change mitigation pledges to the UNFCCC, which forms the heart of the Paris Climate Agreement with its reliance on states' nationally determined mitigation strategies. Importantly, China managed to speed up the implementation of developed countries' pre-2020 climate actions: as a result of China's diplomatic efforts, the UN conference in 2017 decided that additional stocktaking sessions regarding progress in emissions reduction and climate finance be held in the following years. For the future of global efforts to tackle climate change, a crucial question is whether China will be using its growing leverage to re-establish the bifurcation of developed and developing countries held back by the Paris Agreement or whether it will implement ambitiously low carbon development plans that halt its emissions growth as soon as possible and inspire the entire international society to implement efficient emissions reductions in time.

\section{China as an Arctic great power}

In this section, I discuss the construction of China's great power status in the context of Arctic affairs. Although the concept of great power is very vague and the requirements for its recognition are not crystal clear, it has become increasingly evident that China can no longer be excluded from the 'great power club' (Bull, 2002 [1977], p. 194; Wight, 1999 [1946], p. 42; Kopra, 2019a, p. 70-73). The English School conception of great power integrates the realist and constructivist perspectives: it assumes that "even if a state reaches a certain level of material capacity and has a certain national identity, it does not automatically become a great power, but instead needs to be recognised and accepted by other recognised great powers" (Kopra, 2019b, p. 153). As discussed above, responsibility is an important attribute of being a great power from the English School theory point of view. Therefore, I largely focus on China's great power identity and its notions of great power responsibility in the Arctic and pay less attention to the material aspects of China's great power status, which have been extensively studied elsewhere (see, for example, Brady, 2017). That said, we cannot fully understand a state's identity and beliefs without knowing its (material) interests. In China's great power status-building, two 'centenary goals' to be achieved by 2049 , the 100th anniversary of the founding of the PRC, no doubt play a central role. Hence, I give a short introduction to China's interests in the Arctic and discuss how the state's Arctic activities seek to advance the construction of its great power status.

China published its long-awaited white paper entitled China's Arctic Policy in January 2018 in order to clarify its visions and interests regarding the Arctic - thus decreasing the international speculations and various "China threat theories" (see Deng, 2008) that its growing regional role has fuelled. The paper sums up China's Arctic policy goals as follows: 'to understand, protect, develop and participate in the governance of the Arctic, so as to safeguard the common interests of all countries and the international community in the Arctic, and promote sustainable development of the Arctic' (State Council Information Office of the People's Republic of China, 2018). For a long time, China's polar interests were chiefly scientific in nature. It signed the Svalbard Treaty in 1925, and Chinese scholars started to conduct research and take part in international research projects in the Arctic in the early 1990s. In 2004, China's first Arctic research station was established in Ny Alesund, Svalbard, and in 2018, the China-Iceland Arctic Science Observatory began to operate at Karholl, near the town of Akureyri in northern Iceland. China's first home-built icebreaker, Xuelong II, will be finished in 2019 - well

\footnotetext{
${ }^{1}$ The two centenary goals were originally introduced by the then-President Jiang Zemin at the 15th National Congress of the Chinese Communist Party in 1997. However, the current president, Xi Jinping, elevated them to being China's strategic priorities. They read as follows: 1) 'doubling the 2010 GDP and per capita income of urban and rural residents and finishing the building of a society of initial prosperity in all respects' and 2) 'turning China into a modern socialist country that is prosperous, strong, democratic, culturally advanced and harmonious’ by 2049 (Xinhua 2014).
} 
before the United States even starts to build its new heavy icebreaker. ${ }^{2}$ In addition to scientific research, economic interests are today an important driver of China's Arctic engagement. According to the U.S. Geological Survey (2008), the 'extensive Arctic continental shelves may constitute the geographically largest unexplored prospective area for petroleum remaining on Earth', and these resources clearly are of interest to China because of its growing hunger for oil, gas and other natural resources that are essential to its economy. To get access to those resources, the Chinese have increased cooperation with transnational corporations and the Arctic states - especially in Russia's Yamal Peninsula, where Chinese partners take part in Yamal LNG, one of the largest liquefied natural gas (LNG) projects in the world. In addition, China 'hopes to work with all parties to build a "Polar Silk Road" through developing the Arctic shipping routes' (State Council Information Office of the People's Republic of China, 2018). In particular, Russia's Northern Sea Route is of special interest to China, as it makes it possible to ship LNG from Yamal to China and offers faster and shorter access to the European market.

Growing strategic interests in the Arctic have also increased China's desire to take part in the practices of Arctic regional governance. Being a non-Arctic state, however, China is not eligible to be a full member of the Arctic Council, the key regional forum established in 1996 to enhance cooperation and to coordinate interaction amongst the eight Arctic states and Arctic Indigenous communities on sustainable development and environmental protection in the region. Yet, China got the status of permanent observer in the Arctic Council in 2013, which provides it access to the Council's activities but no right to participate in decision-making. To increase its leverage in regional affairs, China has actively taken part in informal forums of Arctic governance, such as Arctic Frontiers in Tromso and the Arctic Circle in Reykjavik. Interestingly, two high-level Chinese representatives spoke at the opening session of the Arctic Circle Assembly in 2017 - while American representatives were conspicuous by their absence - and in 2018, the "China Night" event organised by the Chinese Embassy in Iceland "marked another highlight of the assembly" (Ministry of Foreign Affairs of the PRC, 2018). Despite their historic tensions, China has also launched a new joint regional initiative with Japan and Korea, the Trilateral High-Level Dialogue on the Arctic, in which the Arctic states can only take part as observers. Moreover, China officially added the Arctic dimension to president Xi Jinping's grand foreign policy initiative, One Belt, One Road, in June 2017 (Xinhua, 2017). China has also increased science diplomacy and bilateral cooperation with many Arctic states. For example, the China-Nordic Arctic Research Center was established in 2013 and diplomatic relations with the Nordic countries are now promoted via the so-called 5+1 diplomacy model (see Sverdrup-Thygeson, Lindgren \& Lanteigne, 2018).

In order to legitimise its growing role in the Arctic, China has started to cultivate an image of a 'near-Arctic state'. According to China's Arctic white paper, China is an 'important stakeholder' as well as an 'active participant, builder and contributor in Arctic affairs who has spared no efforts to contribute its wisdom to the development of the Arctic region' and who 'commits itself to maintaining a peaceful, secure and stable Arctic order' (State Council Information Office of the People's Republic of China, 2018). When it comes to international peace and security, the white paper stresses that 'Peace and stability in the Arctic... serves the fundamental interest of all countries including China'. Although the strategy describes China as a 'responsible major country', it does not otherwise make an explicit reference to China's great power status nor to the related great power responsibilities. Yet, it hints that such responsibilities can be attached to China's regional role: 'As a permanent member of the UN Security Council, China shoulders the important mission of jointly promoting peace and security in the Arctic' (ibid.). In line with this, the white paper pledges to commit to existing international law and to respect the sovereign rights of the Arctic states as well as the interests of other states and the broader international society when promoting China's own interests in the region. Overall, the Chinese government constantly underlines China's benevolent role in international affairs, including the Arctic. As for environmental responsibilities, the Arctic white paper assures the world that 'China always gives top priority to resolving global environmental issues, earnestly fulfills [sic] its obligations under relevant treaties, and discharges its responsibility of environmental protection' (ibid.).

\footnotetext{
${ }^{2}$ For further information on China's (scientific) presence in the Arctic, see Brady (2017).
} 
While China does not assume great power responsibility in the Arctic, the Arctic white paper does not refer to great power rights, either. This comes as no surprise: such formulation would probably be viewed as threatening rhetoric by the Arctic states and would not support China's pursuit to portray an image of a benevolent actor in the Arctic and beyond. Yet, the white paper makes it very clear that China, an external actor in the region, possesses international rights in the Arctic - and the Arctic states are to respect them. The strategy indeed argues for China's rights to conduct scientific research, navigate, overfly, fish, lay submarine cables and pipelines as well as explore and exploit natural resources in the high seas, to name a few. To justify these international rights in the Arctic region clearly, the Chinese government has adopted a rhetoric strategy that highlights the global dimensions and transformation of the region. In particular, China's Arctic white paper pays surprisingly little attention to the role of the Arctic Council in regional governance and describes the Arctic more or less as a global common. According to the white paper, the "Arctic situation now goes beyond its original inter-Arctic States or regional nature, having a vital bearing on the interests of States outside the region and the interests of the international community as a whole, as well as on the survival, the development, and the shared future for mankind' (State Council Information Office of the People's Republic of China, 2018). In this way, China seems to pursue to advance a discursive shift from a territorial definition of the region towards a more globalised understanding of the region. If successful, this strategy is likely to alter the discourses on international security as well.

\section{China and climate security in the Arctic}

There is a scientific consensus on climate change being a real global problem exacerbated by human activities, especially by the burning of fossil fuels such as coal and oil. Since greenhouse gas emissions do not respect borders of sovereign states but float throughout the atmosphere, climate change is a global problem that no individual nation-state can solve (or escape) on its own. Therefore, global cooperation and solutions are necessary. Since the early 1990s, international negotiations on climate change have been conducted under the UNFCCC. Owing to its position as the greatest carbon emitter and its status of an emerging great power, China now plays a gatekeeper's role in those negotiations. As China's contribution to the UNFCCC has been discussed elsewhere (e.g. Kopra, 2019a), in this chapter I will examine the ways in which China's official statements regarding Arctic affairs conceptualize climate change. In particular, I elaborate on whether China's Arctic policies and strategies address great power responsibility for climate change, and if so, how they are used to legitimate China's role in the regional governance.

At present, China's carbon emissions account for about 30 percent of the global greenhouse gas emissions, which means that China is now the largest carbon emitter in the world. China seeks to halt its carbon emissions growth by 2030 but it remains unclear how much those emissions will grow before the peak. It seemed that the peak was reached between 2014 and 2016, but in 2017 the emissions rose again because of an increasing demand of coal, oil and gas (Climate Action Tracker, 2018). Furthermore, China is also a significant source of short-lived climate pollutants (SLCPs) - especially black carbon and methane - that are important contributors to climate change. Approximately 20 percent of the warming and snow-ice cover loss in the Arctic is attributed to the reduction of the albedo effect (i.e. Earth's ability to reflect sunlight) caused by black carbon emissions (Koch et al. 2011). Yet, the international legal and governance regime steering the reduction of SLCPs in the Arctic is complex and fragmented (Yamineva \& Kulovesi, 2018), and China's air quality policies have not addressed black carbon per se, probably because of a lack of scientific knowledge on the substance and on the interconnections between air quality, public health and climate policies (Yamineva \& Liu, 2019).

In essence, China's Arctic policy does not make any new contributions to international climate politics or efforts to reduce black carbon emissions. The white paper acknowledges that China's emissions reduction measures have a 'positive impact on the climatic and ecological environment of the Arctic' but does not pledge China to enhance those actions. Since the strategy seems to take the legitimation of China's Arctic engagement as its ultimate goal, it pays more attention to the nexus between China's domestic climate security and Arctic climate 
change than to the state's own contribution to the latter. That said, Arctic climate change undoubtedly is an important driver of China's Arctic engagement, as recent scientific findings show that the melting of Arctic icecaps increases haze pollution in eastern China (Wang, Chen \& Liu, 2015); causes flooding in many of China's coastal mega-cities including Shanghai, Tianjin and Hong Kong; and alters many global natural processes that may hinder agricultural production in China. Air pollution and food security are of significant interest to the Chinese party-state because they have a great impact on social stability in the country and thereby on the legitimacy of the Chinese Communist Party itself. Therefore, the Arctic white paper stresses the importance of scientific research on Arctic climate change and its global ramifications, and China wants to learn more about its domestic (security) implications. This knowledge may help improve its climate change adaptation plans, which is highly relevant from the viewpoint of Chinese leadership's domestic responsibility, given the poor preparedness of the entire Chinese society to deal with risks posed by climate change (see China's National Development and Reform Commission, 2013).

In terms of global climate leadership, however, China's Arctic white paper misses a great opportunity to convince the world of the state's commitment to climate change mitigation and to making climate responsibility an important attribute of great power responsibility. Since China is the greatest carbon emitter in the world, it is also the most significant contributor to Arctic climate change. When China's Arctic white paper was published, an established (Arctic) great power, the United States, had abandoned the Paris climate agreement, making the future of international climate negotiations look rather grim. Since Russia as another Arctic great power has not showed much willingness to tackle climate change either, China could have rather easily elevated its profile in international society by introducing new, ambitious measures to mitigate climate change. At present, China's nationally determined contribution to the $\mathrm{UNFCCC}^{3}$ is 'highly insufficient' to reach the goals of the Paris climate agreement unless other states increase their level of ambition (Climate Action Tracker, 2018). The Intergovernmental Panel on Climate Change (IPCC) has made it very clear that to prevent the most dangerous climate change from happening, we must reduce the global net carbon emissions by 45 percent from the 2010 level by 2030 (IPCC, 2018). Hence, all states should upgrade their climate mitigation pledges, as they are currently not sufficient to limit the global temperature rise to $2{ }^{\circ} \mathrm{C}$, not to mention $1.5^{\circ} \mathrm{C}$ that the IPPC defines as a safer upper limit to global warming. Like many other countries, China is not very eager to commit itself to quantitative emission reduction targets at a global level, since it would 'lose face' if it failed to meet them. Therefore, the bottom-up approach of the Paris climate agreement is particularly appealing to China. In political terms, however, China's Arctic white paper could have shown global leadership by announcing new domestic measures to mitigate climate change for the protection of the Arctic. Such an announcement would have demonstrated that China has truly taken the driver's seat in international climate politics. Besides, there are strong domestic incentives to decrease the use of coal, for instance, because of a growing discontent over environmental pollution amongst Chinese citizens. Moreover, such an announcement might have increased the willingness of the wider international community to recognize China as a legitimate stakeholder in the Arctic and beyond.

\section{Conclusions}

Overall, Arctic engagement plays an important role in China's efforts to become an established great power in terms of economy, technology, knowledge and policy. Although China is a non-Arctic state, it has found ways to increase its leverage in the domains of economy, science diplomacy and bilateral cooperation with several Arctic states, especially Russia and the Nordic countries. As China's military and technological capabilities have been discussed in previous literature, I chose not to discuss the material aspects of China's great power status in this

\footnotetext{
${ }^{3}$ China's current nationally determined contribution to the UNFCCC reads as follows: a) To achieve the peaking of carbon dioxide emissions around 2030 and making best efforts to peak early; b) To lower carbon dioxide emissions per unit of GDP by $60 \%$ to $65 \%$ from the 2005 level; c) To increase the share of non-fossil fuels in primary energy consumption to around $20 \%$; and d) To increase the forest stock volume by around 4.5 billion cubic meters on the 2005 level (China's National Development and Reform Commission, 2015).
} 
chapter. Instead, I focused on China's great power identity and corresponding notions of responsibility in the Arctic in general, and climate responsibility in particular. Climate change is indeed a central issue in view of China's increasing role in the Arctic: China argues that because of the adverse effects of climate change, it has special interests in the Arctic and must therefore have a chance to engage in Arctic governance. In other words, China uses climate change as a key justification for its Arctic engagement.

There is a growing consensus in international society that climate change is a threat in terms of both traditional and non-traditional definitions of security. From the viewpoint of English School theory, it means that great powers must shoulder a special responsibility in responding to climate change. Although China has sought to define climate responsibility as an attribute of great power responsibility at a global level (Kopra, 2019a), its Arctic policy makes no reference to this special responsibility nor demonstrates any kind of leadership in global efforts to tackle climate change - an omission very critical to international (climate) security. Under the presidency of Donald Trump, the United States has also failed to live up to its great power climate responsibility. If the next U.S. president does not renew American great power leadership in international climate politics, China's emerging climate leadership becomes even more critical in the future. For China, there are strong domestic incentives to take the findings of the IPCC (2018) seriously. In addition to national security interests, the "greenification" of economy supports China's structural reforms and development plans. Thus, taking a stronger leadership role in international climate politics would probably not be a big sacrifice for China. Conversely, such a leadership role would significantly improve its status as a responsible great power - a status that would bring along privileges in international society, perhaps including more room to manoeuvre in the Arctic. Since notions of great power responsibility derive from practices of security politics, however, it is not very likely that either China or the United States will assume a strong climate leadership role without a profound transformation in the discourses and premises of international security. What we need, hence, is a paradigm shift in international security: climate change must be identified as a key security threat of our times. In practice, it would mean that great powers are no longer able to carry out their special responsibility to maintain international peace and security without taking a lead in international efforts to prevent dangerous climate change from happening.

\section{Acknowledgements}

The author wishes to thank the Academy of Finland (project no. 315402) for funding this research, and the editors as well as Karoliina Hurri for their constructive feedback on the earlier versions of this chapter.

\section{References}

ACIA (2004) Impacts of a Warming Arctic: Arctic Climate Impact Assessment. http://amap.no/acia/.

AMAP (2017) Snow, Water, Ice and Permafrost in the Arctic (SWIPA) 2017. Arctic Monitoring and Assessment Programme, https://www.amap.no/documents/doc/Snow-Water-Ice-and-Permafrost-in-the-Arctic-SWIPA2017/1610.

Bukovansky, Mlada, Ian Clark, Robyn Eckersley, Richard Price, Christian Reus-Smit and Nicholas J. Wheeler. (2012) Special Responsibilities. Global Problems and American Power (New York: Cambridge University Press).

Bull, Hedley (2002 [1977]) The Anarchical Society.A Study of Order in World Politics. Third edition. (Basingstoke: MacMillan Press).

Brady, Anne-Marie (2017) China as a Polar Great Power (Cambridge: Cambridge University Press).

Cassotta, S., Hossain, K., Ren, J. Z., \& Goodsite, M. E. (2015) "Climate Change and China as a Global 
Emerging Regulatory Sea Power in the Arctic Ocean: Is China a Threat for Arctic Ocean Security?”, Beijing Law Review 6, 199-207. http://dx.doi.org/10.4236/blr.2015.63020.

China’s National Development and Reform Commission (2013) 国家适应气候变化战略 [National Climate Change Adaptation Strategy] http://www.sdpc.gov.cn/zcfb/zcfbtz/201312/W020131209343322750059.pdf

China's National Development and Reform Commission (2015) Enhanced action on climate change: China's intended nationally determined contributions, http://www4.unfccc.int/ndcregistry/PublishedDocuments/China\%20First/China\%27s\%20First\%20NDC\%20Sub mission.pdf

Climate Action Tracker (2018) China, https://climateactiontracker.org/countries/china/

Deng, Y. (2008) China's Struggle for Status. The Realignment of International Relations (Cambridge: Cambridge University Press).

Falkner, Robert (2012) "Global environmentalism and the greening of international society", International Affairs 88:3, 503-522.

Falkner, Robert and Buzan, Barry (2018) "The emergence of environmental stewardship as a primary institution of global international society", European Journal of International Relations.

IPCC (2018) Global Warming of $1.5^{\circ} \mathrm{C}$. An IPCC Special Report on the impacts of global warming of $1.5^{\circ} \mathrm{C}$ above pre-industrial levels and related global greenhouse gas emission pathways, in the context of strengthening the global response to the threat of climate change, sustainable development, and efforts to eradicate poverty. (Geneva, Switzerland: World Meteorological Organization).

Jackson Robert H. (2000) The Global Covenant (Oxford: Oxford University Press).

Koch, D., S.E. Bauer, A. Del Genio, G. Faluvegi, J.R. McConnell, S. Menon, R.L. Miller, D. Rind, R. Ruedy, G.A. Schmidt and D. Shindell (2011). "Coupled aerosol-chemistry-climate twentieth-century transient model investigation: Trends in short-lived species and climate responses", Journal of Climate, 24, 2693-2714.

Kopra, Sanna (2019a) China and Great Power Responsibility for Climate Change (London and New York: Routledge).

Kopra, Sanna (2019b) "China, Great Power Management, and Climate Change: Negotiating Great Power Climate Responsibility in the UN" in Tonny Brems Knudsen and Cornelia Navari (eds.) International Organization in the Anarchical Society. The Institutional Structure of World Order (New York: Palgrave Macmillan).

Lee, James R. (2009) Climate Change and Armed Conflict. Hot and Cold Wars (London: Routledge).

Krause-Jackson, Flavia (2013) "Climate Change's Links to Conflict Draws UN Attention" Bloomberg, February 15. http://www.bloomberg.com/news/articles/2013-02-15/climate-change-s-links-to-conflict-draws-un-attention.

Mazo, Jeffery (2010) Climate Conflict. How global warming threatens security and what to do about it (London: Routledge).

Mearsheimer, J. J. (2001) The Tragedy of Great Power Politics (New York: W.W. Norton \& Company). 
Ministry of Foreign Affairs of the PRC (2018) China Night Lights Up 2018 Arctic Circle Assembly, https://www.fmprc.gov.cn/mfa_eng/wjb_663304/zwjg_665342/zwbd_665378/t1606536.shtml

Obama, Barack (2014) Remarks by the President at U.N. Climate Change Summit, https://obamawhitehouse.archives.gov/the-press-office/2014/09/23/remarks-president-un-climate-changesummit.

Rainwater, S. (2013). "Race to the North. China's Arctic Strategy and Its Implications", Naval War College Review, 66 (2).

Serreze, Marc C. (2018) Brave New Arctic. The Untold Story of the Melting North (Princeton: Princeton University Press).

Shambaugh, David (2013) China goes global: the partial power (New York: Oxford University Press).

State Council Information Office of the People's Republic of China (2018) China's Arctic Policy, http://english.gov.cn/archive/white_paper/2018/01/26/content_281476026660336.htm

Sverdrup-Thygeson, Bjørnar, Wrenn Yennie Lindgren \& Marc Lanteigne (eds.) (2018) China and Nordic Diplomacy (London \& New York: Routledge).

Trombetta, Maria Julia (2008) "Environmental security and climate change: analysing the discourse", Cambridge Review of International Affairs 21: 4, 585-602.

United Nations (2007) Security Council holds first-ever debate on impact of climate change on peace, surety, hearing over 50 speakers, http://www.un.org/press/en/2007/sc9000.doc.htm.

UN General Assembly (2009a) Climate change and its possible security implications. A/RES/63/281, 85th plenary meeting, June 3 .

UN General Assembly (2009b) Climate change and its possible security implications. Report of the SecretaryGeneral.A/64/350, September 11.

UN Security Council (2011) Statement by the President of the Security Council. S/PRST/2011/15, July 20.

UN Security Council (1992) Note by the president of the Security Council. S/23500, January 31.

U.S. Geological Survey (2008) Circum-Arctic Resource Appraisal: Estimates of Undiscovered Oil and Gas North of the Arctic Circle, http://pubs.usgs.gov/fs/2008/3049/fs2008-3049.pdf

Wang Hui-Jun,Chen Huo-Po and Liu Jiping (2015) “Arctic Sea Ice Decline Intensified Haze Pollution in Eastern China”, Atmospheric and Oceanic Science Letters 8 (1), 1-9.

Watson, Adam (1982) Diplomacy. The Dialogue Between States (London: Eyre Methuen).

Welzer, Harald (2012) Climate Wars: why people will be killed in the twenty-first century. Translated by Patrick Camiller (Cambridge: Polity Press).

White House (2017) Statement by President Trump on the Paris Climate Accord, https://www.whitehouse.gov/briefings-statements/statement-president-trump-paris-climate-accord/ 
White House (2016a) U.S.-China Joint Presidential Statement on Climate Change, https://obamawhitehouse.archives.gov/the-press-office/2016/03/31/us-china-joint-presidential-statement-climatechange.

White House (2016b) U.S.-China Climate Change Cooperation Outcomes, https://obamawhitehouse.archives.gov/the-press-office/2016/09/03/fact-sheet-us-china-cooperation-climatechange.

White House (2015) U.S.-China Joint Presidential Statement on Climate Change, https://obamawhitehouse.archives.gov/the-press-office/2015/09/25/us-china-joint-presidential-statement-climatechange.

White House (2014), U.S.-China Joint Announcement on Climate Change, https://www.whitehouse.gov/the-pressoffice/2014/11/11/us-china-joint-announcement-climate-change.

White House (2013) Joint U.S.-China Statement on Climate Change, https://20092017.state.gov/r/pa/prs/ps/2013/04/207465.htm.

Wight, Martin (1999 [1946]) Power Politics (London: Leicester University Press).

Xinhua (2017) Vision for Maritime Cooperation under the Belt and Road Initiative, http://www.xinhuanet.com/english/2017-06/20/c_136380414.htm.

Xinhua (2014) Xi eyes more enabling int'l environment for China's peaceful development, http://en.people.cn/n/2014/1130/c90883-8815967.html.

Wright, C.D. (2011) The Dragon Eyes the Top of the World. Arctic Policy Debate and Discussion in China. China Maritime Institute, U.S. Naval War College, http://www.usnwc.edu/Research---Gaming/China-MaritimeStudies-Institute/Publications/documents/China-Maritime-Study-8_The-Dragon-Eyes-the-Top-of-.pdf.

Xi, Jinping (2017) Secure a Decisive Victory in Building a Moderately Prosperous Society in All Respects and Strive for the Great Success of Socialism with Chinese Characteristics for a New Era, http://www.xinhuanet.com/english/download/Xi_Jinping's_report_at_19th_CPC_National_Congress.pdf.

Yamineva, Yulia and Kati Kulovesi (2018) "Keeping the Arctic White: The Legal and Governance Landscape for Reducing Short-Lived Climate Pollutants in the Arctic Region”, Transnational Environmental Law, 7:2 (2018), 201-227.

Yamineva, Yulia and Zhe Liu (2019) "Cleaning the air, protecting the climate: Policy, legal and institutional nexus to reduce black carbon emissions in China", Environmental Science \& Policy, 95, 1-10.

Zhang, Gaoli (2014) Build Consensus and Implement Actions For a Cooperative and Win-Win Global Climate Governance System, http://www.fmprc.gov.cn/mfa_eng/zxxx_662805/t1194637.shtml. 